prior to RTX. At the end of follow-up, no significant change was revealed in FVC when compared with pre-RTX values [58.0 (44.7-58.7), $\mathrm{p}=0.065]$. FVC was improved in four patients and stabilized remaining ten patients. All of the patients with improvement of PFTs had moderate or severe restrictive lung disease. High resolution thorax computed tomography (HRCT) findings remained stable in 7 and showed progression of ILD in 3 patients. In total, mRSS remained stable at the end of follow-up when compared with baseline [8.0 (5.2-12.2) vs. 6.0 $(4.0-12.2), p=0,026]$.

Table 1. Demographic, clinical and laboratory data of patients

\begin{tabular}{|c|c|c|c|c|c|c|c|c|}
\hline \multirow[t]{2}{*}{$\begin{array}{l}\text { Age/ } \\
\text { Sex }\end{array}$} & \multirow{2}{*}{$\begin{array}{c}\text { Disease } \\
\text { duration, } \\
\text { years }\end{array}$} & \multirow{2}{*}{$\begin{array}{l}\text { Cutaneous } \\
\text { subset }\end{array}$} & \multirow[t]{2}{*}{$\begin{array}{c}\text { Auto- } \\
\text { antibodies }\end{array}$} & \multirow{2}{*}{$\begin{array}{l}\text { Previous immuno- } \\
\text { supresive } \\
\text { treatment }\end{array}$} & \multirow{2}{*}{$\begin{array}{l}\text { RTX } \\
\text { cycles }\end{array}$} & \multirow{2}{*}{$\begin{array}{l}\text { Follow-up } \\
\text { after RTX, } \\
\text { months }\end{array}$} & \multicolumn{2}{|c|}{$\begin{array}{c}\text { FVC } \\
\text { (predicted\%) }\end{array}$} \\
\hline & & & & & & & $\begin{array}{c}\text { Before } \\
\text { RTX }\end{array}$ & $\begin{array}{l}\text { After } \\
\text { RTX }\end{array}$ \\
\hline $52 / F$ & 7.0 & Diffuse & ANA, Scl-70 & CYC, MMF & 2 & 12 & 44 & 44 \\
\hline 39/M & 10.1 & Diffuse & ANA, Scl-70 & MMF & 4 & 24 & 75 & 79 \\
\hline $55 / F$ & 5.0 & Diffuse & ANA, Scl-70 & MMF & 4 & 24 & 75 & 70 \\
\hline $43 / F$ & 16.6 & Limited & ANA, Scl-70 & CYC, MMF & 1 & 6 & 38 & 47 \\
\hline $50 / F$ & 4.6 & Limited & ANA, Scl-70 & CYC, MMF & 4 & 24 & 52 & 57 \\
\hline $65 / F$ & 13,0 & Diffuse & ANA, Scl-70 & CYC, MMF & 1 & 6 & 42 & 41 \\
\hline $48 / \mathrm{F}$ & 5.7 & Limited & ANA, Scl-70 & CYC & 4 & 24 & 67 & 64 \\
\hline $54 / F$ & 18.9 & Diffuse & ANA, Scl-70 & CYC, MMF & 2 & 12 & 39 & 57 \\
\hline $53 / F$ & 15.0 & Limited & ANA, Scl-70 & CYC, MMF & 5 & 30 & 53 & 44 \\
\hline $56 / F$ & 5,1 & Limited & ANA, Scl-70 & CYC & 1 & 6 & 40 & 45 \\
\hline $52 / F$ & 8.2 & Limited & ANA & - & 3 & 12 & 59 & 59 \\
\hline 18/F & 11.2 & Diffuse & ANA, Scl-70 & MMF & 1 & 6 & 63 & 73 \\
\hline $62 / F$ & 4.6 & Limited & ANA, Scl-70 & CYC, MMF & 3 & 18 & 51 & 61 \\
\hline $54 / \mathrm{F}$ & 13.1 & Limited & ANA, Scl-70 & CYC, MMF & 5 & 30 & 54 & 67 \\
\hline
\end{tabular}

FVC, forced vital capacity; ANA, antinuclear antibody; Scl-70, antitopoisomerase-1 antibody; CYC, cyclophosphamide; MMF,mycophenolate mofetil; RTX, rituximab.

Conclusions: In this case series of SSc patients treated with RTX, improvement or stabilization of pulmonary functions was observed in most of SSc patients. RTX may be useful in SSc-ILD patients with longer disease duration and resistant to conventional immunsupresive therapies.

Disclosure of Interest: None declared

DOI: 10.1136/annrheumdis-2017-eular.5501

\section{AB0605 VITAMIN D SERUM CONCENTRATION IN EUROPEAN SYSTEMIC SCLEROSIS PATIENTS: CORRELATIONS WITH SEASONALITY, ORGAN INVOLVEMENT AND STANDARD ORAL SUPPLEMENTATION}

A.C. Trombetta ${ }^{1}$, V. Smith ${ }^{2}$, E. Gotelli ${ }^{1}$, M. Ghio ${ }^{1}$, S. Paolino ${ }^{1}$, C. Pizzorni ${ }^{1}$, A. Sulli ${ }^{1}$, M. Cutolo ${ }^{1} .{ }^{1}$ Research Laboratory and Academic Division of Clinical Rheumatology, Department of Internal Medicine, University of Genoa, Genoa, Italy; ${ }^{2}$ Department of Internal Medicine, Faculty of Medicine and Health Sciences; Department of Rheumatology, Ghent University Hospital, Ghent University, Ghent, Belgium

Background: Vitamin D deficiency is reported to interfere with immune responses and to correlate with course and outcome in several autoimmune diseases. In systemic sclerosis (SSc), low 25-hydroxyvitamin D (25(OH)D) serum concentration has been recognized.

Objectives: To investigate relations between 25(OH)D serum concentration and seasonality, clinical parameters as well as standard oral supplementation, in SSc patients.

Methods: 154 SSc patients (mean age $59 \pm 15$ years, $24.7 \%$ diffuse form and $75.3 \%$ limited form) were evaluated, at any time of the year, in a retrospective survey. Serum $25(\mathrm{OH}) \mathrm{D}$ quantification was performed using the LIAISON 25-OH vitamin $D$ assay (Diasorin, Italy). Pulmonary function test, chest $x$-ray, lung CT scan, electrocardiography, Doppler echocardiography, renal artery resistive index by eco color Doppler, Dual X-ray absorptiometry, were performed at the time of sample collection. Disease severity scale (DSS) was performed according to Medsger. Drug assumption (glucocorticoids, calcium channel blockers, cyclic intravenous iloprost, endothelin receptor antagonists) and supplementation with vitamin $\mathrm{D}$ analogues, were recorded. Non-parametric tests were used for statistical analysis.

Results: Average $25(\mathrm{OH}) \mathrm{D}$ serum concentration was found to be $18.7 \pm 9 \mathrm{ng} / \mathrm{ml}$ ( $<20$ classified as deficiency). A significant difference was observed among seasonal $25(\mathrm{OH}) \mathrm{D}$ serum concentration (winter: $14.6 \pm 7.8 \mathrm{ng} / \mathrm{ml}$, spring: $17.2 \pm 7.9$ $\mathrm{ng} / \mathrm{ml}$, summer $21.43 \pm 10 \mathrm{ng} / \mathrm{ml}$, autumn $20.2 \pm 10 ; \mathrm{p}=0.032$ ) (Figure 1 ). A significant correlation was found between 25(OH)D serum concentration and presence/absence of bi-basal fibrotic changes at lung computed tomography (CT) scan (average values: $16.1 \pm 8 \mathrm{ng} / \mathrm{ml}$ and $20 \pm 10 \mathrm{ng} / \mathrm{ml}$, respectively, $p=0.04$ ). Peripheral vascular ( $p=0.03)$, kidney $(p=0.02)$, gastrointestinal $(p=0.05)$ Medsger's DSS parameters also were found to correlate with $25(\mathrm{OH}) \mathrm{D}$ serum concentration (Figure 1). Interestingly, no influence of treatment with vitamin $D$ analogues $(1,000$ UI daily) was found regarding $25(\mathrm{OH}) \mathrm{D}$ serum concentration in treated $(18.8 \pm 10$ $\mathrm{ng} / \mathrm{ml})$ and in not treated $(18.7 \pm 9 \mathrm{ng} / \mathrm{ml})$ SSc patients $(p=0.81)$.

Conclusions: In SSc is confirmed a serum $25(\mathrm{OH}) \mathrm{D}$ deficiency that we report to be associated with lung involvement, peripheral vascular, kidney and gastrointestinal Medsger's DSS parameters, as well as with seasonality. Supplementation with vitamin D analogues did not influence present results.

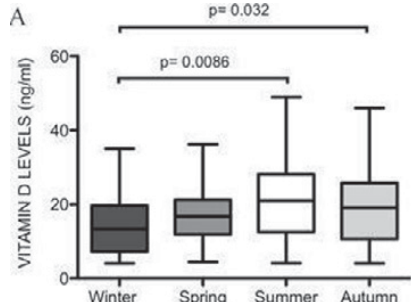

B
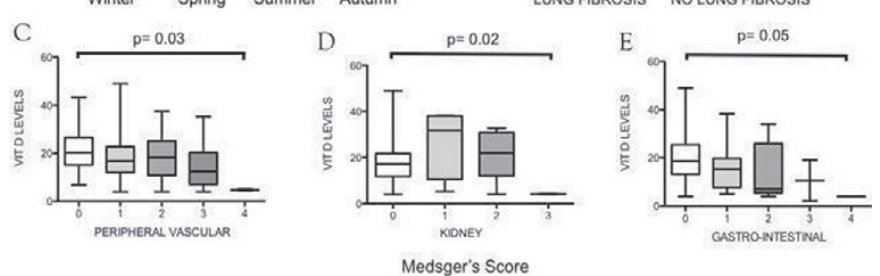

Therefore, for successful replacement, supra-physiological oral vitamin D3 doses or programmed UVB light exposure should be considered.

Disclosure of Interest: None declared

DOI: 10.1136/annrheumdis-2017-eular.4919

\section{AB0606 MORTALITY ASSOCIATED FACTORS TO IDIOPATHIC INFLAMMATORY MYOPATHIES (IIMS)}

A.C. Costi ${ }^{1}$, P. Sansinanea ${ }^{1}$, C. Pena ${ }^{1}$, A. Testi $^{1}$, A. Salas ${ }^{1}$, J. Marcos ${ }^{1}$,

V. Arturi ${ }^{1}$, A. Vulcano ${ }^{1}$, M. Pera ${ }^{1}$, R. García Salinas ${ }^{2}$, R. Aguila Maldonado ${ }^{1}$,

L. García Var ${ }^{1}$, V. Nagua ${ }^{1}$, M.A. García ${ }^{1}$. ${ }^{1}$ Rheumatology, HIGA San Martín;

${ }^{2}$ Rheumatology, Hospital Italiano, la Plata, Argentina

Background: Idiopathic inflammatory myopathies (IIMs) include a group of muscular diseases characterized by the presence of muscle inflammation. The mortality of the IIMs has been estimated between 13 and $50 \%$.

Objectives: To evaluate mortality rate and associated factors in patients with IIMs.

Methods: Retrospective, observational study, where patients with IIMs (Bohan \& Peter 1975) were included. Data were obtained from medical records from patients with myopathy (Increase CK, muscle weakness, cutaneous involvement, interstitial lung involvement) evaluated in a reference rheumatology center of Argentina (1992-2016). Descriptive statistics were performed. Chi2 test, Student's test or Mann Whitney as appropriate multivariate logistic regression analysis.

Results: From 102 patients evaluated 89 enter the study, 73\% were female. Mean age at diagnosis $48 \pm 14$ years. Clinical Manifestations: Skin involvement $77 \%$ (erythema Heliotrope $51 \%$, rash on the neck and V-sign $60 \%$, back and shoulders $50 \%$, photosensitivity $60 \%$, Gottron's papules $50 \%$, pruritus $33 \%$, erythema peri nail $21 \%$ ), pulmonary involvement $19 \%$ Raynaud $28 \%$, muscle weakness $86 \%$, muscle weakness of the neck $33 \%$, respiratory muscles $13 \%$, myalgias $60 \%$ and dysphagia $53 \%$

Muscle biopsy: performed in 36/89 with pathological findings in $83 \%$, electromyogram performed in 35\%. Intensive care unit admission 14/89 (16\%). Laboratory: raised CPK 68\% with an mean value $3527 \mathrm{lU} / \mathrm{ml}$, raised Transaminase $60 \%$, ANA positive $65 \%$, SSA/RO 25\%, Jo1 4.4\%, RNP 7\%, increased CRP $28 \%$ and ERA $59 \%$.

Clinical Subtypes IIMs: Dermatomyositis (DM): 61\%, Antisynthetic syndrome (AS): $6 \%$, Myopathy associated with connective tissue disease: $19 \%$, Associated with statins: $4,4 \%$, Polimyositis: $10 \%$. Association with neoplasia was observed in $15 \%$. Treatments: Corticoids pulses $21 \%$, corticoids $97 \%$ (mean starting dose $45 \mathrm{mg}$ meprednisone), methotrexate $77 \%$, hydroxychloroquine $36 \%$, azathioprine $30 \%$, cyclophosphamide $16 \%$, intravenous immunoglobulin $15 \%$, biological $10 \%$ and cyclosporine $3 \%$.

Univariate analysis

\begin{tabular}{lccc}
\hline Variables & Mortality (Odds Ratio) & $95 \%$ IC & \\
\hline Male sex & 3 & $1,03-8,4$ & $\mathrm{P}<0,039$ \\
Respiratory muscle weakness & 5,47 & $\mathrm{IC}: 1,4-20,59$ & $\mathrm{P}<0,007$ \\
ANA positive & 6 & $1,27-27$ & $\mathrm{P}<0,01$ \\
Neoplasms & 3,8 & $1,1-1,3 \mathrm{p}$ & $\mathrm{P}<0,026$ \\
Glucocorticoid pulses & 5,7 & $1,81-17,8$ & $\mathrm{P}<0,001$ \\
Intravenous immunoglobulin & 3,67 & $1,06-12,6$ & $\mathrm{P}<0,03$ \\
Serious infections & 17 & $4,6-61,5$ & $\mathrm{P}<0,0000012$ \\
\hline
\end{tabular}

Multivariate analysis of logistic regression

\begin{tabular}{lcccc}
\hline Variable & OR & \multicolumn{2}{c}{ IC $(95,0 \%)$} & $\mathrm{p}$ \\
\hline Malignant neoplasm & 8,785 & 1,229 & 62,797 & $\mathbf{0 . 0 3}$ \\
Serious infections & 69,168 & 10,079 & 474,666 & $\mathbf{0 . 0 0 0 1}$ \\
Glucocorticoid pulses & 3,745 & 0,635 & 22,092 & 0.145 \\
Male sex & 5,899 & 1,141 & 30,504 & $\mathbf{0 . 0 3 4}$ \\
Intravenous immunoglobulin & 0,906 & 0,100 & 8,217 & 0.93 \\
Respiratory muscle weakness & 0,524 & 0,050 & 5,527 & 0.59 \\
ANA positive & 4,247 & 0,638 & 28,259 & 0.135 \\
\hline
\end{tabular}

